\title{
Occurrence of Cryptosporidium spp. and Giardia spp. in pigs at weaning
}

\section{Ocorrência de Cryptosporidium spp. and Giardia spp. em suínos ao desmame}

\author{
Denise Junqueira Matos ${ }^{1 *}$; Marcelo Vasconcelos Meireles²; \\ Willian Marinho Dourado Coelho ${ }^{3}$; Katia Denise Saraiva Bresciani ${ }^{4}$
}

\begin{abstract}
Cryptosporidium spp. and Giardia spp. are parasites and have been reported in many species of mammals, including humans. The goal of this research was to investigate the occurrence of Cryptosporidium spp. and Giardia spp. in 45-days-old pigs. Fecal samples of 107 pigs were collected at three alternate days in piggeries in Araçatuba, São Paulo State, Brazil. Cryptosporidium oocysts were observed in 4.7\% (5/107) of animals by Kinyoun acid-fast stain method and cysts of Giardia spp. were observed in $1.9 \%(2 / 107)$ of the animals by the method of Faust. Of all animals, 85 presented feces with normal consistency and 22 showed diarrhea in at least one collection. Two diarrheic samples showed positivity for both Cryptosporidium spp. and Giardia spp. From these results it is possible to infer that the occurrence of Cryptosporidium and Giardia was low because of the good management practices and both protozoa were not associated the presence of symptoms.
\end{abstract}

Key words: Protozoonosis. Cysts. Diarrhea. Feces. Oocysts. Piggery.

\section{Resumo}

Cryptosporidium spp. e Giardia spp. são parasitas e têm sido relatados em várias espécies de mamíferos, incluindo humanos. O objetivo deste trabalho foi investigar a ocorrência de Cryptosporidium spp. e Giardia spp. em suínos de 45 dias de idade. Amostras fecais de 107 suínos foram coletadas em três dias alternados de pocilgas em Araçatuba, São Paulo, Brasil. Oocistos de Cryptosporidium foram observados em 4,7\% (5/107) dos animais por meio do método de Kinyoun e cistos de Giardia spp. em 1,9\% (2/107) dos animais pelo método de Faust. Dentre os animais, 85 apresentaram fezes com consistência normal e 22 com diarréia em pelo menos uma coleta. Em duas amostras diarreicas foram observadas presença de oocistos de Cryptosporidium spp. e cistos de Giardia spp. A partir destes resultados é possível inferir que a ocorrência de Cryptosporidium e Giardia foi baixa devido a práticas de boa gestão e que ambos os protozoários não foram associados à presença de sintomas.

Palavras-chave: Protozoonose. Cistos. Diarreia. Fezes. Oocistos. Pocilga.

\footnotetext{
${ }^{1}$ Discente de Doutorado do Curso de Pós-Graduação em Ciência Animal da Faculdade de Medicina Veterinária, UNESP, Campus de Araçatuba, Prof ${ }^{a}$, Centro Universitário Católico Salesiano Auxilium, UniSalesiano, Araçatuba, SP, Brasil. E-mail: dejunmatos@ hotmail.com

2 Prof. Adjunto, Departamento de Clínica, Cirurgia e Reprodução Animal, UNESP, Campus de Araçatuba Araçatuba, SP, Brasil. E-mail: marcelo@fmval.unesp.br

${ }^{3}$ Dr., Curso de Pós-Graduação em Medicina Veterinária da Faculdade de Ciências Agrárias e Veterinárias, UNESP, Campus de Jaboticabal, Prof., Faculdade de Ciências Agrárias de Andradina, FCAA, Andradina, SP, Brasil. E-mail: willianmarinho@, hotmail.com

${ }^{4}$ Prof $^{a}$ Adjunto, Departamento de Apoio, Produção e Saúde Animal, UNESP, Campus de Araçatuba, Araçatuba, SP, Brasil. E-mail: bresciani@fmval.unesp.br

* Autor for correspondence
} 
Cryptosporidium and Giardia may cause significant economic losses by weight reduction in piglets (HAMNES et al., 2007). Researchers in several countries reported a prevalence of Cryptosporidium spp. in a range between 1.4 and $33.2 \%$ for domestic pigs (WIELER et al., 2001; NGUYEN et al., 2012).

Cyptosporidium species have been reported worldwide in domestic pigs (JENÍKOVÁ et al., 2011; KVÁC et al., 2013). It was particularly incident between the sixth and the $12^{\text {th }}$ weeks of life, which is a stage in the post-weaning period (MADDOX- HYTTEL et al., 2006; HAMNES et al., 2007; JOHNSON et al., 2008). Giardia has been reported between 11 and 18 days of age (HAMNES et al., 2007). Fecal shedding of cysts of these protozoa was intermittent with a pattern similar to several other animal species (HAMNES et al., 2007).

The goal of this research was to investigate the occurrence of Cryptosporidium spp. and Giardia spp. in 45-days-old pigs in Araçatuba, São Paulo, Brazil. The experimental group was carried all (three) existing sities of Araçatuba, São Paulo, Brazil, during the year 2007 and 2008, with all pigs from 45 days of age (15 days after weaning), consisting of 107 piglets comprising 60 females and 47 males belonging to landrace or hybrid (Landrace and Large White) breeds in piggeries.

Piggeries 1 and 3, respectively with 59 and 36 pigs, had all animals removed from pens for seven days and during this period disinfectants like quaternary ammonia compounds, iodine and formaldehyde were then alternately used and animals were introduced only after the facilities were completely dry. Blowtorches were used three times a year. Piggery 2, with 12 animals, had animals removed for up to two months and blowtorches used up to five times per year together with cresols and lime.
All three piggeries had featured intensive production with water and food administered ad libitum. The animals were separated in lots and kept in elevated pens or over cement flooring with daily cleaning with high pressure water. Ivermectin $1 \%$ was given to the sows 15 days before parturition and to the post weaning piglets.

Three fecal samples of all litters were collected on alternate days from February to November 2008. Feces were collected directly from the rectal ampulla of each animal and processed following the centrifuge-flotation technique (FAUST et al., 1938) with a zinc sulfate solution (density $1,200 \mathrm{~g} \cdot \mathrm{cm}^{-3}$ ) for the detection of Giardia spp. cysts. Next, the fecal smears were stained by the Kinyoun acidfast stain (LENNETTE, 1985), for detection of Cryptosporidium spp. oocysts.

A fecal sample was prepared including variables such as sex, breed, consistency and hydration of fecal samples of each animal as well as the structure and sanitary management of each piggery.

Samples positive for both parasites were detected in July. Giardia spp. has a greater incidence in the seasons in which temperature is cooler (SILVA et al., 2007). This fact can be explained by the fact that animals are bunched together for warmth (ABRANTES; SILVEIRA, 2009).

In addition to the diagnostic technique, the management seems to have some influence on positivity since all examined animals were confined to elevated pens with concrete flooring. Open air raising presented a higher rate of occurrence of Giardia spp. and Cryptosporidium spp. when compared to indoor piggeries (JOHNSON et al., 2008).

The period of 21 days after weaning is considered a critical stage in pig production due to stressing factors, like separation from the sows or change in environment and nutrition, which may cause diarrhea (LIMA; MORÉS; SANCHES, 2009). Clostridium perfringens, Escherichia 
coli, rotaviruses, Isospora suis and Strongyloides ransomi may be held as possible causal agents of enteric manifestations (LIPPKE et al., 2011).

Of all animals, 85 presented feces with normal consistency and 22 showed diarrhea in at least one collection. Of these, two demonstrated concomitant positivity for Cryptosporidium spp. and Giardia spp. Despite the positive findings, the cause of those diarrhea instances is not certain since no other copro-parasitological tests have been carried out in those pigs. Previously have reported significant association between diarrhea and Cryptosporidium positivity in piglets (HAMNES et al., 2007) end presence of Cryptosporidium was not significantly associated with decreased fecal consistency in pigs in Central Vietnam (NGUYEN et al., 2012).

Using the direct immunofluorescence microscopy (DFA) technique, Budu-Amoako et al. (2012) found 26\% (163/ 633) of piglets positive for Cryptosporidium spp. in Canada. In Brazil, Quadros et al. (2006) did not observe positivity for Cryptosporidium in swines of different ages using the auramine-O dye and the Ziehl Neelsen technique.

Daily pen cleaning with high pressure water, the use of disinfectants, adequate food, water from artesian wells given by nipple feeders, concrete floors or elevated pens and the habit of the pigs to defecate always in the same place are factors that reduce agent presence in the environment and must have contributed to the low parasitic occurrence observed in this study.

Formaldehyde and iodine have bactericidal and germicidal properties. Lime associated with water it generates a large amount of heat thus featuring a high disinfectant value (SOBESTIANSKY et al., 1981). Maddox-Hyttel et al. (2006) observed that the cleaning of the floor (high pressure water, disinfection and drying the premises before introduction of animals) have reduced the excretion of Giardia cysts and of Cryptosporidium oocysts.

Animals were positive for Cryptosporidium spp. or Giardia spp. at only one of three collections. Among those positive for Cryptosporidium spp., two were found at the first collection ( $45^{\text {th }}$ day) and three at the second one ( $47^{\text {th }}$ day), while those positive for Giardia presented the parasite at the second collection only (47 th day). These results agree with the findings of Guselle et al. (2003) who evaluated cryptosporidiosis in swine. Hamnes et al. (2007) also concluded that Giardia cysts are excreted in a non-continuous way in other animals, probably showing the same pattern in pigs.

\section{Conclusions}

From the results obtained, it is possible to infer that occurrence of Cryptosporidium and Giardia is low in post-weaning piglets in piggeries with good sanitary management and with adequate facilities.

\section{References}

ABRANTES, P.; SILVEIRA, H. Alterações climáticas na Europa: efeito nas doenças parasitárias humanas. Revista Portuguesa de Saúde Pública, Lisboa, v. 27, n. 2, p. 7186, 2009.

BUDU-AMOAKO, E.; GREENWOODC, S. J.; DIXOND, B. R.; BARKEMA, H. W.; HURNIKA, D.; ESTEYA, C.; MCCLUREA, J. T. Occurrence of Giardia and Cryptosporidium in pigs on Prince Edward Island, Canada. Veterinary Parasitology, Amsterdam, v. 184, n. 1, p. 18-24, 2012.

FAUST, E. C.; D' ANTONI, J. S.; ODON, V.; MILLER, M. S.; PERES, C.; SAWITZ, W.; TOMEN, L. F.; WALKER, J. H. A critical study of clinical laboratory techinics for the diagnosis of protozoan cysts and helminth eggs in feces. I-Preliminary communication. American Journal of Tropical Medicine and Hygiene, Deefield, v. 18, n. 2, p. 169-183, 1938.

GUSELLE, N.; APPELBEE, A. J.; OLSON, M. E. Biology of Cryptosporidium parvum in pigs: from weaning to market. Veterinary Parasitology, Amsterdam, v. 113, n. 1, p. 7-18, 2003.

HAMNES, I. S.; GJERDE, B. K.; FORBERG, T.; ROBERTSON, L. J. Occurrence of Cryptosporidium and Giardia in sucking piglets in Norway. Veterinary Parasitology, Amsterdam, v. 144, n. 3-4, p. 222-233, 2007. 
JENÍKOVÁ, M.; NEMEJC, K.; SAK, B.; KVETO NOVÁ, D.; KVÁC, M. New view on the age-specificity of pig Cryptosporidium by species-specific primers for distinguishing Cryptosporidium suis and Cryptosporidium pig genotype II. Veterinary Parasitology, Amsterdam, v. 176, n. 2-3, p. 120-125, 2011.

JOHNSON, J.; BUDDLE, R.; REID, S.; ARMSON, A.; RYAN, M. Prevalence of Cryptosporidium genotypes in pre and post-weaned pigs in Austrália. Experimental Parasitology, San Diego, v. 119, n. 3, p. 418-421, 2008.

KVÁC，M.; KESTRÁNOVÁ, M.; PINKOVÁ, M.; KVETO NOVÁ, D.; KALINOVÁ, J.; WAGNEROVÁ, P.; KOTKOVÁ, M.; VÍTOVEC, J.; DITRICH, O.; MCEVOY, J.; STENGER, B.; SAK, B. Cryptosporidium scrofarum n. sp. (Apicomplexa:Cryptosporidiidae) in domestic pigs (Sus scrofa). Veterinary Parasitology, Amsterdam, v. 191, n. 3, p. 218-227, 2013.

LENNETTE, E. H. Manual of clinical microbiology, $4^{\text {th }}$ ed. Washington: American Society for Microbiology, 1985. 1149 p.

LIPPKE, R. T.; BOROWSKI, S. M.; MARQUES, S. M. T.; PAES, S. O.; ALMEIDA, L. L.; MORENO, A. M.; CORBELlINI, L. G.; BARCELLOS, D. E. S. N. Matched case-control study evaluating the frequency of the main agents associated with neonatal diarrhea in piglets. Pesquisa Veterinária Brasileira, Seropédica, v. 31, n.6, p. 505-510, 2011.

LIMA, G. J. M. M.; MORÉS, N.; SANCHES, R. L. As diarreias nutricionais na suinocultura. Acta Scientiae Veterinariae, Porto Alegre, v. 37, p.17-30, 2009. Suplemento 1.
MADDOX-HYTTEL， C.; LANGKJAER， R. S.; RIKKE, B.; ENEMARK, H. L.; HEIDI, L.; VIGRE, P. H. Cryptosporidium and Giardia in different age groups of Danish cattle and pigs: occurrence and management associated risk factors. Veterinary Parasitology, Amsterdam, v. 141, n. 1-2, p. 48-59, 2006.

NGUYEN, S. T.; HONMA, H.; GEURDEN, T.; IKARASH, M.; FUKUDA, Y.; HUYNH, V. V.; NGUYEN, D. C.; NAKAI, Y. Prevalence and risk factors associated with Cryptosporidium oocysts shedding in pigs in Central Vietnam. Research in Veterinary Science, Oxford, v. 93, n. 2, p. 848-852, 2012.

QUADROS, R. M.; MARQUES, S. M. T.; AMENDOEIRA, C. R.; SOUZA, L. A.; AMENDOEIRA, P. R.; COMPARIN, C. C. Detection of Cryptosporidium oocysts by auramine and Ziehl Neelsen staining methods. Parasitologia Latinoamericana, Santiago, v. 61, n. 3-4, p. 117-120, 2006.

SILVA, A. S.; CEOLIN, L. V.; CARGNELUTTI, J. F.; PESSOA, G. A.; OLIVEIRA, C. B.; QUINTAL, A. P. N.; MONTEIRO, S. G. Prevalência de parasitismo em cães domiciliados em um bairro de Santa Maria - RS. Saúde, Santa Maria, v. 33, n. 1, p. 27-31, 2007.

SOBESTIANSKY, J.; SILVEIRA, P. R. S.; WENTZ, I.; PROTAS, J. F. Limpeza e desinfecção na suinocultura: aspectos técnicos e econômicos. Concórdia: EMBRAPA, CNPSA, 1981. 36 p. (Circular técnica, 3).

WIELER, L. H.; ILIEFF, A.; HERBST, W.; BAUER, C.; VIELER, E.; BAUERFEIND, R.; FAILING, K.; KLOS, H.; WENGERT, D.; BALJER, G.; ZAHNER, H. Prevalence of enteropathogens in suckling and weaned piglets with diarrhoea in southern Germany. Journal of Veterinary Medicine Series B, Germany, v. 48, n. 2, p. 151-159, 2001. 